DOI: 10.35774/app2021.01.120

УДК 347.15/.17:614.256

\section{Наталія Башурин}

асистент кафедри судочинства

навчально-наукового юридичного інститут

ДВНЗ «Прикарпатський національний

університет імені Василя Стефаника»
ORCID: htps:/lorcidorg/0000-0002-5096-0734

\section{ТЕОРЕТИКО-ПРАВОВІ АСПЕКТИ РОЗУМІННЯ НАУКОВО-ТЕХНІЧ-}

\section{НОЇ ІНФОРМАЦІї ЯК ОБ'ЄКТА ЦИВІЛЬНИХ ПРАВОВІДНОСИН}

У статті розглядаються питання комплексного характеру правового регулювання сфери відносин приводу науково-технічної інформаиії із пріоритетністю застосування інструментарію иивільного права. Та кож аргументовано, що відомості, які становлять інформаиію (чи науково-технічну інформацію), можуть потрапляти під правову охорону як законодавства про авторське право, так ізаконодавства про захист права промислової власності за умови наявності у них ознак даних об' 'єктів права інтелектуальної власності. Автором проаналізовано основні концепції щодо розуміння прав, які виникають з об' 'єктів права інтелектуально власності і наголомено на правильності переходу до кониепиії виключних майнових прав щодо науково-технічної інформаиії як об'єкта права інтелектуальної власності.

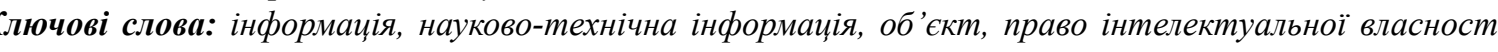
авторське право, патентне право.

Бамурын $\boldsymbol{H}$.

Теоретико-правовые аспекты понимания научно-технической информации как объекта гражданских правоотночений

В статье рассматриваются вопросы комплексного характера правового регулирования сферы отношений по поводу научно-технической информачии с приоритетностью применения инструментария гражданского права. Также аргументировано, что сведения, составляющие информаиию (или научно-техническую информаиию), могут попадать под правовую охрану как законодательства об авторском праве, так и законодательства о защите права промыиленной собственности при наличии у них признаков данных объектов права интеллектуальной собственности. Автором проанализированы основные концепции относительно понимания прав, возникающих из объектов права интеллектуальной собственности, и отмечена правильность перехода к концепции исключительных имущественных прав на научно-техническую инфориацию как объекта права интеллектуальной собственности.

Ключевые слова: информаиия, научно-техническая информация, объект, право интеллектуальной собственности, авторское право, патентное право.

Bashuryn $N$.

Theoretical and legal aspects of understanding scientific and technical information as an object of civil relations

The author emphasizes the complex nature of legal regulation of information relations with the priority of using the tools of civil law. It is also argued that STI as an object of intellectual property rights includes such a set of features as: creative nature; originality; novelty; objective form of expression. In addition, the article proves, that information (or scientific and technical information) may fall under the legal protection of both copyright law and legislation on the protection of industrial property rights, provided that they have signs of these objects of intellectual property law.

The article analyzes the basic concepts of understanding the rights arising from the objects of intellectual property rights: 1) the theory of understanding the objects of intellectual property rights as objects of property righ (the so-called proprietary theory), 2) the theory of exclusive rights to objects of intellectual property rights, including property rights to information as an object of intellectual property rights, in connection with a set of such arguments 1) the right to scientific and technical information and ownership of the thing in which it is embodied, do not depend on each other; $b$ ) when the right to scientific and technical information is transferred, there is no transfer of ownership to the form in which it is materialized: c) a thing that is a form of materialization of scientific and technical information is a document, information product, information resource, etc.

\section{() Наталія Башурин, 2021}

The author argues that the concept of exclusive intellectual property rights is characterized by such a set of features as: a) includes both property and non-property rights to the objects of intellectual property rights; b) the in of exclusive rights; c) a specific set of powers, including: the right to use use. Ihe right to dispose of an exclusive right, exists in two forms: granting the right and transfer of the right; $e$ ) the 政

Keywords: information, scientific and technical information, object, intellectual property law, copyright, patent

Постановка проб̆леми. На сучасному етапі розвитку суспільства науково-технічна інформація $\epsilon$ затребуваним об'єктом цивільного обороту. По суті, даний різновид інформації є основою розвитку та прогресу в різних сферах життедіяльності, а, отже, $є$ фінансово привабливим для інвесторів. У частині розуміння науково-технічної інформації з позицій приватного права слід наголосити, що на сьогодні провідними фахівцями у цій сфері, зокрема О. В. Кохановською, абсолютно слушно наголошується, шо сере двох концепцій розуміння інформаційних прав - концепції інформаційного права як самостійної галузі права і приватноправової конщепшії інформагійних відносин як інституту шивільного права, пріоритет у застосуванні мас друга із них, шо, як наголошус дослідниця, с не тільки правильним в теоретичному аспекті, а й відповідає сучасним суспільним запитам [5, с. 129].

Звісно, що на сьогодні не можна заперечувати комплексність правового регулювання сфери інформаційних відносин. Тут мають своє застосування норми різних галузей права, проте пріоритетність у застосуванні, безумовно, належить інструментарію права цивільного. Йдеться про розуміння інформаційних відносин як відносин приватноправових, а самої інформації, в тому числі, науково-технічної, як оборотоздатного об'єкта цивільного права.

Але науково-технічна інформація як об’єкт цивільних правовідносин $є$ складною за своїм змістом, характеризується переліком специфічних ознак, а це спричиняє певні особливості статики та динаміки цього об’єкта у цивільному обороті. Варто наголосити, що у профільному Законі України «Про науковотехнічну інформацію» [8] законодавцем втілені відповідні посили на приватноправові механізми у визначенні її правового режиму. Так, зокрема, вказується, що така інформація є об'єктом права інтелектуально власності, може бути об'єктом товарних відносин, забезпечуються відповідні механізми систематизаці такої інформації та гарантії доступу до неї іншим особам, при цьому, захищаючи суб’єкта, якому така інформація належить

Аналіз останніх досліджень і публікацій. Питанням інформації в якості об’єкта цивільних правовідносин присвячені праці таких вчених, як Кохановська О.В., Петров Є.В., Марценюк О.Г., Харитоново O.I., Спасибо-Фатєєвої І.Б., Стефанчука Р.О. та багато інших, однак питання, власне, науково-технічно інформації в якості об’єкта цивільних прав потребує подальшого наукового дослідження і вдосконалення правового регулювання.

Метою статті є з'ясування специфіки науково-технічної інформації я комплексного об'єкта цивільних прав і визначення правового режиму, котрий може застосовуватися до неї, враховуючи всю специфіку іiі ознак та форм вираження.

Виклад основного матеріалу дослідження. Справді, питання правомірності використання науково-технічної інформації повинні перебувати в центрі прискіпливої уваги законодавця, з тим, щоб було зрозуміло, чи $\epsilon$ порушенням використання тієї чи іншої інформації для подальшої розробки, створенн технології, патентування об'сктів промислової власності, створених на основі ії результатах, чи мас місие правомірне використання науково-технічної інформації.

3 цією метою та з позицій правомірності її використання необхідно охарактеризувати таку інформацію як об'єкт приватноправових відносин, зокрема, розкрити ії правову природу через характеристику особливостей, що їй притаманні, встановити місце такого виду інформації серед об’єктів цих правовідносин, що й становить мету цієї статті.

Науково-технічна інформація (далі - НТІ) як об'єкт цивільних правовідносини абсолютно вписується у видову характеристику подібних об’єктів, оскільки вміщує як складову особистих немайнових та майнових відносин, так і абсолютного або ж відносного правовідношення, складову виключних майнових правовідносин та зобов'язальних правовідносин.

Вищенаведеній концепції щодо приватноправового характеру інформаційних відносин (відносин щодо науково-технічної інформації як їх різновиду) відповідає підхід щодо розуміння інформації у трьох iі іпостасях : 1) як особисте немайнове благо; 2) як результат творчої, інтелектуальної діяльності, тобто 
як об'єкт виключних прав; 3) як інформаційний продукт, ресурс, документ, тобто об’єкт, який може бути інформаційним товаром i предметом будь-яких правочинів, з урахуванням особливостей $і$ специфіки його як об'єкту особливого роду [9, с. 34]. Спробуємо розглянути кожен із цих проявів НТІ

Приналежність науково-технічної інформації до особистих немайнових прав вказує на такі її характеристики як: непорушність; належність творцю, невідчужуваність, невіддільність від особи, позбавленість майнового змісту, безстроковий та абсолютний характер. При цьому захисту такої інформації в ї̈̈ леність майнового змісту, безстроковий та абсолютний характер. При цьому захисту такої інформаціі в

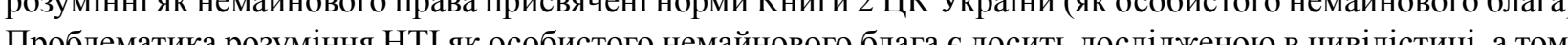
Проблематика розуміння НТЯ як особистого немайнового блага є досить дослідженою в цивілістиці, а тому не вбачасмо потреби у більш детальній характеристиці, проте наголошуємо, що вищенаведені характеристики НТІ як блага є цінними в часлині іі розуміння як об єкта права інтелектуальної власності. Особлив цінність в аспекті особистих немайнових прав на науково-технічну інформацію складає право на недоторканність інформації та збереження ії у визначеному вигляді.

Виходячи $з$ цього права, можна додати до ознак науково-технічної інформації її недоторканність, тобто неможливість змін чи будь-яких інших дій не уповноваженою на те особою. Фактично така ознака випливає із характеристики немайнових правовідносин як абсолютних, коли праву особи протиставляється обов'язок всіх інших осіб не втручатися у існуючі правовідносини.

Справді, як зазначалося вище, норми цивільного права регулюють правовідносини щодо науковотехнічної інформації як продукта інтелектуальної творчості. У такому прояві НТІ характеризуватиметься як загальними ознакам об'єктів цивільного права, в основі яких лежить критерій іхх оборотоздатності, так ознаками, які характерні для іiі розуміння з позицій права інтелектуальної власності.

Переходячи до аналізу ознак НТІ як об'єкта права інтелектуальної власності, варто наголосити, що у цивільному законодавстві закріплена презумпція, за якою «результат інтелектуальної діяльності вважається створеним творчою працею, якщо не доведено інше». Аналогічна презумпція підтримуеться також судовою практикою.

Міжнародно-правові стандарти щодо ознак об’ектів права інтелектуальної власності втілені у міжнародних конвенціях. До прикладу, ознаки правової охорони творів якісно розкрито у Бернській конвеншії про охорону літературних і художніх творів, зокрема такі ознаки як: творчий характер; об’єктивна форма про охорону літературних і худож.

Аналіз загальнотеоретичних засад про особливості інформаційних об'єктів права та об’єктів права інтелектуальної власності дозволяє зробити такий досить важливий висновок: відомості, що становлять інформацію (чи НТІ) можуть потрапляти під правову охорону законодавства про авторське право або ж законодавства про захист права промислової власності. У зазначеному контексті переконливо та аргументовано виглядає аналіз проявів та напрямків розуміння цивільно-правової норми, що здійснений О. В. Кохановською. Дослідниця аналізуе норму цивільного права не тільки в контексті її традиційного розуміння як «загальнообов' язкового формально визначеного правила поведінки», але і як специфічного інформаційного об'єкта і об' 'єкта творчості (авторського права).

Процес творіння норми права, як слушно вказує вчена, носить характер творчої діяльності авторів, у результаті чого виступає об’єктом авторського права. Одночасно сам зміст норми права повине відповідати усім рисам інформації щодо якості: достовірність, актуальність, повнота. Офіційне прийняття законодавчого акта перетворює правову норму з об’єкта авторського права на інформацію (відкриту чи певними обмеженнями щодо доступу) [6, c.151]. Наведені положення справді переконливо демонструют комплексний характер інформаційних відносин загалом та відносин щодо НТІ зокрема, та можливість застосування у регламентації цих відносин як положень законодавства про авторське право, так і норм інформаційного законодавства.

Аналогічна ситуація є в частині розуміння НТІ і як об'єкта права промислової власності, і як інфорправа, в інших - об'єкта права вромислосової власе мати у певних випадках ознаки об’єкта авторського прав такі прояви носять переважно допоміжний характер, який, однак, в певних випадках може набувати ознак основного.

Наведемо приклад HTI, яка об'єктивована на електронних чи матеріальних носіях і, набувши відповідної матеріалізованої форми, містить ознаки об'єкта права інтелектуальної власності. При шьому порушені саме права інтелегтуальної власності (авторські права чи права промислової власності у залежносі від специфіки відомостей, що становлять НТІ), а не інформаційні права. В даному разі слід звертатися до розуміння НТІ через призму її характеристик як об'єкта права інтелектуальної власності. У даному раз пріоритетним $є$ розуміння НTI саме з позицій права інтелектуальної власності.

Якщо ж НТІ містить в собі ознаки комерційної таємниці і за режимом доступу повинна перебувати в обмеженому доступі, проте перебувала у відкритому доступі, тут повинен надаватися пріоритет нормам інформаційного законодавства, адже порушення прав інтелектуальної власності шодо НТІ не мали місця.

Можна навести і ще один можливий випадок. У процесі використання НTI мало місце порушення як прав інтелектуальної власності, що були присутні в НТІ, так й інформаційних прав щодо НТІ. У такому разі слід комплексно кваліфікувати правовідносини щодо НТІ із одночасним застосування норм законодавства у сфері інтелектуальної власності та інформаційного законодавства.

Може мати місце також ситуація, коли відомості, що складають HTI, не містять проявів об’єкта права інтелектуальної власності, у такому разі застосовуватиметься виключно інформаційне законодавство при врегулюванні спорів щодо НТІ

Отже, для правильної кваліфікації відносин щодо НТІ важливо у кожному конкретному випадку розуміти наявність чи відсутність у НТІ проявів об’єкта права інтелектуальної власності, а якщо такі мають місце, то носять вони основний чи допоміжний характер. Ці характеристики мають особливе значення, адже впливають на визначення норм, які слід застосовувати у відносинах, які складаються щодо НТІ як складного за змістом об'єкта цивільного права.

Якщо розкривати специфіку НТІ з позицій інформаційного права, то для неї характерні такі ідентифікуючі риси: НTI завжди зберігається за суб’єктом, який ії передає; тиражування НTI, що може мати вплив на комерційну цінність інформації, але не на її корисність для суб’єкта, якому належить право на неї або ж для іншого уповноваженого суб'єкта; можливість використання HTI попереднім володільцем може бути обмежена лише через заборону здійснення таких дій, а не шляхом вилучення у попереднього володільця речі-засобу збереження HTI; моментом створення HTI $є$ надання ій певної форми та фіксації на матеріальному чи електронному носії; виключне майнове право на інформацію $є$ строковим; спешифічний правовий режим (за загальним правилом, вільний доступ до НТІ із встановленням законних обмежень у використанні). Наведений перелік ознак с визнанальни для розуміння НTІ в якості об’скта інформаційного права.

Досліджуючи проблематику регулювання науково-технічної інформації з позицій природи відносин права інтелектуальної власності, варто вказати, що на сьогодні $\epsilon$ дві концепції з цього приводу. Так, за першою концепцією пропонується розглядати об'єкти права інтелектуальної власності як об'єкти права власності. Другий підхід пов'язаний із змістом виключних майнових прав щодо об'єкта права інтелектуальної власності, у тому числі інформації. Варто наголосити, що на перший погляд концепція речових прав може бути придатною для науково-технічної інформації як різновиду інформації, тим більше за умов постійного удосконалення теорії речових прав [7; 2] та розширення його об'єктів.

Справді, варто наголосити, що у контексті досліджуваної нами проблеми, важливими є сучасні тенденції, що мають місце у доктрині речового права. Як слушно наголошує Р. А. Майданик, для сучасного речового права характерні певні тенденції, а саме: 1) за своєю структурою система речового права включає в себе загальні положення, володіння та окремі види речових прав; 2) перехід до концепції широкого розуміння речових прав, що обумовлює розширення кола речових прав через включення так званих «прихованих» речових прав; 3) доцільність законодавчого закріплення в положеннях ЦК України в нормах про речі поняття цифрового контенту і цифрової речі та доступ третіх осіб до них [7, с. 16; с. 32]. Одночасно сучасні фахівці у сфері речового права, наголошуючи на концепціі широкого підходу до розуміння речових прав, дуже обережно ставляться до поширення речового-правового регулювання на відносини у сфері інформації. І в цьому є сенс, адже інформація має свою специфіку, на якій ми наголошували вище.

Ще у 2001 р. Р. Б. Шишка, досліджуючи пропрістарну теорію, наголошував на тому, що «вона має свої позитивні сторони - наприклад, консолідувати законодавство про інтелектуальну власність. Одночасно цивіліст зауважив, що ця теорія недостатньо спрацьовує при захисті майнових прав володільців, що обумовлює не необхідність пошуку іншої теорії права інтелектуальної власності, яка б більш точніше відображала зміст цих відносин» [10, с. 315].

Втім, варто наголосити, що раніше ст. 6 Закону України «Про науково-технічну інформацію» проголошувала, шо ця інформація $є$ об'єктом права власності. Такий пілхід по суті був вілображенням проприєтарної теорії. Така тенденшія мала місце ів інших нормативно-правових актах у сфері інтелектуально власності, хоча 32014 р., у зв'язку із внесенням змін, конструкція права власності щодо НТІ була вилучена власності,
із Закону.

ISSN 2524-0129 (Print) / ISSN (2664-5718) (Online). Актуальні проблеми правознавства. 1 (25)/2021 
У доктрині права констатується наявність поряд із речовими та зобов'язальними правами, так званих виключних прав [3, с. 13], що є певною особливістю ЦК України. Поступово проприєтарна теорія прав на інформацію в теорії цивільного права втратила свої переваги $[5 ; 4]$

Справді, на нашу думку, необхідність зміни наукових підходів та їх розвиток - це виклик та необхідність, адже невідповідність правових конструкцій сучасним вимогам та практичним реаліям свідчить про те, що вони не дієві. І в цьому є об’єктивні фактори, які розкриваються у працях багатьох науковців. До прикладу, $Є$. В. Петров на підтвердження нездатності концепції права власності належним чином розкривати сутність правомочностей, що випливають з інформації, наводить наступні аргументи: 1) абсолютно неефективне регулювання відповідних відносин (до нематеріальних об'єктів, зокрема, не може бути застосовано багато з існуючих методів захисту права власності, та й «передача» таких об’єктів за договоро купівлі-продажу навряд чи може бути реалізована у практичній пплощині); 2) правомочності власника не можуть бути адекватно використані для такого нематеріального об’єкта, як інформація, неможливо також застосувати віндикаційний позов; 3) не може бути правомочності володіння, оскільки неможливо володіти та фізично впливати на інформацію; 4) конструкція користування теж не підходить у чистому вигляді для опису і регулювання видобування корисних властивостей з нематеріальних об’єктів; 5) категорія розпорядження, яка встановлена для речей теж не вписується в характеристики інформації [4].

У контексті характеристики правильності переходу до концепціі виключних майнових прав щодо інформаціі важливо наголосити на базовому постулаті, який закладений у Книзі 4 ЦК Украіни (ст. 419) щодо незалежності права інтелектуальної власності та права власності на річ, в тому числі при переході права на об'єкт права інтелектуальної власності чи права власності на річ [9]. Якщо інтерпретувати дане положення під науково-технічну інформацію, то варто вказати, що право на НТІ та право власності на річ, в якій втілена НTI, не залежать одне від одного. При переході права на НTI, не відбувається переходу прав власності на форму, в якій вона уречевлена і навпаки. При цьому річчю, яка виступає формою уречевленн HTI виступає документ, інформаційних продукт, інформаційних ресурс тощо.

Висновок про можливість віднесення НTI до об'єктів, на які поширюється правовий режим виключних мйнових прав обумовлений проявами у НTL характеристик об'єктів права інтелектуаль власності, про й влаженнях ЦК Украйни (ч. 1 ст. 421 ЦК Укрӓ̈н [9] та харх

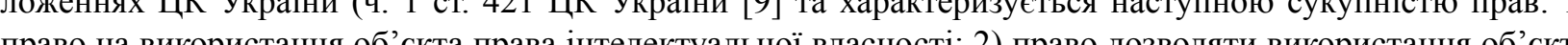

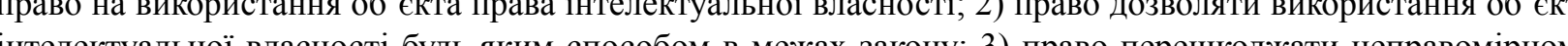
інге тер викор стал льної власності.

Сучасна доктрина цивільного права характеризується серйозним та грунтовним рівнем напрацювань проблематики виключних прав інтелектуальної власності. Серед основних положень тезисно можн окреслити такі найважливіші: а) конструкція виключних прав включає в себе як майнові, так і немайно права щодо об'єктів права інтелектуальної власності; б) абсолютний характер виключних прав, що проявляється в обов'язку всіх і кожного утримуватися від використання у всіх або у визначених формах об’єкт права інтелектуальної власності; в) специфічна сукупність правомочностей, що включають у себе: прав використання та право розпорядження цим використанням) право на розпорядження виключним правом, існує у двох формах: надання права та передання права; д) належність усіх прав на об’єкт права інтелектуальної власності тільки суб'єкту цього права.

Це загалом основні положення, якими характеризуються виключні права інтелектуальної власності та які повною мірою застосовні до НТІ в якості іі розуміння як об єкта права інтелектуальної власності. Водночас висловити думку, що напрацювання та категоріальний апарат речового права до даних відносин не застосовується взагалі - також неправильно. До прикладу, конструкція «дозволяти використання» НTI (виступи на основі створеної науково-технічної інформації, відкриття НТІ до вільного доступу) чи інші форми використання НТІ в основі свого розуміння базуються на повномочності користування, звісно, з урахуванням специфіки НТІ як блага, і як об’'єкта права інтелектуальної власності та інформаційного права. Іншим прикладом, що базується на основі конструкцій речового права $є$ конструкція розпорядження, що проявляється у можливості визначити юридичну долю об'єкта правовідносин інтелектуально власності (як реальну, так і юридичну), наприклад, передати права на неї, звісно у видозміненому прояв. Розпорл жатись НTI - ше право відуужувати, дарув тури так званих «інших майнових прав інтелектуальної власності».

ISSN 2524-0129 (Print)/ ISSN (2664-5718) (Online). Актуальні проблеми правознавства. 1 (25)/2021
3 урахуванням наведеного, для виключного майнового права на НТІ не можуть бути характерні відносини власності або ж класичного володіння. Наведений підхід також відображений у чинному про-

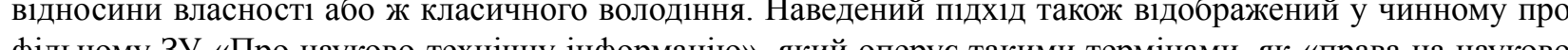
фем

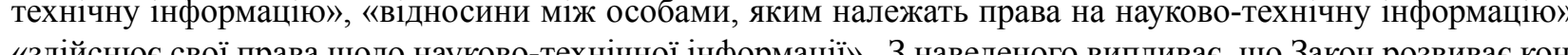
цепцію викл логічно [8].

Висновки. Підсумовуючи наведене, варто наголосити на перспективності застосування саме приватноправової теорії регламентації відносин, об’єктом яких виступає інформація загалом, та НТІ зокрема Досліджувані правовідносини носять комплексний характер правового регулювання із пріоритетністю застосування інструме бистого немайнового блага; об’єкта права інтелектуальної власності; інформаційного продукту (ресурсу).

\section{Список використаних джерел}

1. Бернська конвенція про охорону літературних і художніх творів від 24.07.1971. База даних «Законодавство України». URL: http://zakon3.rada.gov.ua/laws/ show/995_051 (дата звернення: 21.12.2020).

2. Гейнц Р. М. Самозахист речових прав. Речове право: пріоритети та перспективи. Матеріали Киїськких правових читань. Київ, 22 березня 2019 р. / Р. А. Майданик, Я. М. Романюк та ін.; відп. ред. Р. А. Майданик. Київ: Алерта, 2019. С. 39-46.

3. Голубєва Н. Ю. Співвідношення зобов'язальних та речових правовідносин. Часопис иивілістики. 2015. Вип. 19. С. 13-17.

4. Калаченкова К., Титова О. Щодо правового режиму інформації у сфері господарювання. Економікоправова парадигма розвитку сучасного суспільства. 2016. №2. URL: https://studlib.org.ua/index.php eprs/article/view/89/85 (дата звернення: 25.01.2021).

5. Кохановська О. В. Приватно-правове розуміння інформаційних відносин в Україні. Часопис иивілістики. 2017. Вип. 22. С. 128-133.

6. Кохановська О. В. Цивільно-правова норма як загальнообов'язкове правило поведінки, інформація і результат творчості. Вісник Національної академії правових наук України. 2018. Т. 25. № 2. С. 142-155.

7. Майданик Р. А. Переосмислення речового права в сучасних умовах. Речове право: пріоритети та перспективи. Матеріали Київських рравових читань. Київ, 22 березня 2019 р. / Р. А. Майданик, Я. М. Романюк та ін.; відп. ред. Р. А. Майданик. Київ: Алерта, 2019. С. 9-33.

8. Про науково-технічну інформацію: Закон України від 25.06.1993. № 3322-ХІІ. Відомості Верховноі Ради України. 1993. N 33. ст. 345.

9. Кохановська О.В. Цивільно-правові проблеми інформаційних відносин в Україні: автореф. дис... д-ра юрид. наук: 12.00 .03 . Київ, 2006. 34 с.

10. Шишка Р.Б. Пропрієтарна теорія інтелектуальної власності. Вісник Харківського національного університету внутрішніх справ. 2001. Вип. 16. С. 311-315.

\section{References}

1. Bernska konventsiia pro okhoronu literaturnykh i khudozhnikh tvoriv vid 24.07.1971 [Berne Convention for the Protection of Literary and Artistic Works of 24.07.1971]. Baza danykh «Zakonodavstvo Ukrainy»Database «Legislation of Ukraine». Retrieved from http://zakon3.rada.gov.ua/laws/show/995_051 [in Ukrainian].

2. Heints, R. M. (2019). Samozakhyst rechovykh prav [Self-protection of property rights]. Rechove pravo. priorytety ta perspektyvy. Materialy Kyivskykh pravovykh chytan - Property Law: priorities and prospects. Materials of Kyiv legal readings. Kyiv, 22 bereznia 2019 r. / R. A. Maidanyk, Ya. M. Romaniuk ta in.; vidp. red. R. A. Maidanyk. Kyiv: Alerta, $39-46$ [in Ukrainian].

3. Holubieva, N. Yu. (2015). Spivvidnoshennia zoboviazalnykh ta rechovykh pravovidnosyn [The ratio of binding and property relations]. Chasopys tsyvilistyky - Journal of Civil Law science, 19, 13-17 [in Ukrainian]

4. Kalachenkova, K. \& Tytova,O. (2016). Shchodo pravovoho rezhymu informatsii u sferi hospodariuvanni [On the legal regime of information in the field of management]. Ekonomiko-pravova paradyhma rozvytku suchasnoho suspilstva - Economic and legal paradigm of modern society, 2. Retrieved from: https://studlib. org.ua/index.php/eprs/article/view/89/85 [in Ukrainian].

ISSN 2524-0129 (Print) / ISSN (2664-5718) (Online), Актүальні проблеми правознавства. 1 (25)/2021 
5. Kokhanovska, O. V. (2017). Pryvatno-pravove rozuminnia informatsiinykh vidnosyn v Ukraini [Private legal understanding of information relations in Ukraine]. Chasopys tsyvilistyky - Journal of Civil Law science, 22, 128-133 [in Ukrainian].

6. Kokhanovska, O. V. (2018). Tsyvilno-pravova norma yak zahalnooboviazkove pravylo povedinky, informatsii i rezultat tvorchosti [Civil law as a mandatory rule of conduct, information and the result of creativity]. Visnyk Natsionalnoi akademii pravovykh nauk Ukrainy - Bulletin of the National Academy of Legal Sciences of Ukraine, 25 (2), 142-155 [in Ukrainian].

7. Maidanyk, R. A. (2019). Pereosmyslennia rechovoho prava v suchasnykh umovakh [Rethinking of Property Law in modern conditions]. Rechove pravo: priorytety ta perspektyvy. Materialy Kyivskykh pravovykh chytan Property Law: priorities and prospects. Materials of Kyiv legal readings. Kyiv, 22 bereznia 2019 r./ R. A. Maidanyk, Ya. M. Romaniuk ta in.; vidp. red. R. A. Maidanyk. Kyiv: Alerta, 9-33 [in Ukrainian]

8. Pro naukovo-tekhichnu informatsit. Zakon Ukrainy vid 25.06.1993 [On scientifc and technical information Law of Ukraine of 25.06.1993]. № 3322-XII. Vidomosti Verkhovnoi Rady Ukrainy - Information of the Verkhovna Rada of Ukraine. 1993, 33, 345 [in Ukrainian].

9. Kokhanovska O. V. (2006). Tsyvilno-pravovi problemy informatsiinykh vidnosyn v Ukraini [Civil Law problems of information relations in Ukraine]: avtoref. dys... d-ra yuryd. nauk: 12.00.03. Kyiv [in Ukrainian].

10. Shyshka, R.B. (2001). Propriietarna teoriia intelektualnoi vlasnosti [Proprietary theory of intellectual property] Visnyk Kharkivskoho natsionalnoho universytetu vnutrishnikh sprav 2001 - Bulletin of Kharkiv National University of Internal Affairs 2001,311-315. Retrieved from http://nbuv.gov.ua/UJRN/VKhnuvs_2001_16 63 in Ukrainian].

4. КРИМІНАЛЬНЕ ПРАВО ТА КРИМІНОЛОГІЯ. КРИМІНАЛЬНО-ВИКОНАВЧЕ ПРАВО. КРИМІНАЛЬНИЙ ПРОЦЕС

ТА КРИМІНАЛІСТИКА. СУДОВА ЕКСПЕРТИЗА. ОПЕРАТИВНО-РОЗШУКОВА ДІЯЛЬНІСТЬ. СУДОУСТРІЙ. ПРОКУРАТУРА ТА АДВОКАТУРА

DOI: 10.35774/app2021.01.127

УДК 343.85:343.378

\section{Ніна Рогатинська,} доктор юридичних наук, в.о.зав.кафедри кримінального права та прочесу і правоохоронноі діяльності Західноукраїського наиіонального університету ORCID:// http://orcid.org/0000-0003-0617-6114

\section{ВПЛИВ КОНТРАБАНДИ НА МИТНУ БЕЗПЕКУ ДЕРЖАВИ}

У статті розглянуто теоретичні питання визначення змісту контрабандної діяльності. Обгрунтовано особливості здійснення контрабанди та її вплив на митну безпеку держави.

Ключові слова: контрабанда, протидія контабанді, митна злочинність, економічна безпека, митна безпека.

\section{Rohatynska N.}

The impact of smuggling on the customs security of the state

The article considers theoretical issues of determining the content of smuggling. The current problems of smuggling, the prerequisites for ils spread in border areas are highlighted. The pecularilies of smuggling and its impact on customs security are substantiated. It is emphasized that one of the main tasks assigned to customs authorities is. among other things, prevention and counteraction to smuggling, combating violations of customs rules throughout the customs territory of Ukraine, as well as exchange of documents and information (including electronic) with other state bodies of Ukraine, customs, law enforcement and other bodies of foreign states. The legal nature of smuggling and it negative impact on customs security has been studied. It is smuggling and violation of customs rules that are the basis for the existence of customs crime. It is an essenial component of economic crime, related to embezzlemen, evasion of customs duties, and the commission of official crimes. The goal of customs security is defined as achieving the level of efficiency and reliability of the customs system due to the productive functioning of customs authorities. Measures aimed () Ніна Рогатинська, 2021 